Future agendas in urban tourism research: Special Editorial

\begin{tabular}{|r|l|}
\hline Journal: & International Journal of Tourism Cities \\
\hline Manuscript ID & IJTC-12-2018-0095 \\
\hline Manuscript Type: & Editorial \\
\hline
\end{tabular}

SCHOLARONE $^{\text {Im }}$

Manuscripts 


\title{
Future agendas in urban tourism research: Special Editorial
}

\author{
Tina Šegota, Marianna Sigala, Ulrike Gretzel, Jonathon Day, Jithendran Kokkranikal, Melanie \\ Smith, Joan C. Henderson, Claudia Seabra, Philip Pearce, Rob Davidson, Cina Van Zyl, David \\ Newsome, James Hardcastle, Tijana Rakić
}

\section{Foreword}

\begin{abstract}
Dr Tina Šegota (University of Greenwich), IJTC Theme Editor of Quality for Life in Tourism Cities
\end{abstract}

Academic researchers were provided with an additional forum to exchange knowledge, research and agendas on the critical study of urban tourism and tourism cities with the emergence of the International Journal of Tourism Cities in 2015. Since then, the Journal has been recognized for its outstanding contribution to urban tourism research by numerous scholars. This recognition was embodied in prestigious academic abstracting and indexing, such as achieving the Emerging Sources Citation Index, and Scopus and SJR indices of above 0.5.

International Journal of Tourism Cities also welcomed numerous international scholars to its editorial board, of which some also serve as the theme editors. Theme editors were invited to provide their insights on future research agendas in urban tourism research. With this gesture, the Journal wishes to mark the celebration of the fifth volume in the fifth year of publishing and many abovementioned recognitions, as well as acknowledging the valuable time and effort of many scholars dedicated to its recent success.

Therefore, this Special Editorial serves as a roadmap for future research on the opportunities and challenges for urban tourism. It initially touches upon more recent technological advancements and their impact on tourism in cities, calling for a better understanding of the concept of smartness and highlighting the importance of social media. Furthermore, sustainability, quality of life, and tourism planning and development have been heavily challenged by sharing economy and tourists' quest for unique experiences enabled by new technologies. Several important questions and perspectives have been outlined - from responsible tourism to ethnoscapes, to acknowledgement that urban tourism not only impacts the quality of life of local residents but also its visitors. Lessons learnt from crises may bring new opportunities for managing urban tourism, just as in the case of Post-Communist countries. However, with the issue of terrorism at every corner of the world, new research on crisis management is anticipated. Looking further down the line of challenges for urban tourism, tourists' behaviour has dynamically changed with the help of new technologies. So, has the behaviour of business travellers, for whom we need a better understanding of their experiences of being invited, to attend, to post-travel behaviour in relation to business events. Moreover, there is a need for a better understanding of special interest tourism and its impact on tourism management, supply and demand business perspectives, and host community. Similarly, new research agendas should also focus on the conservation of nature and its importance for city 
tourism. In conclusion, the Special Editorial brings a fresh perspective on new visual research methodology that offers numerous possibilities for research by elicitation of techniques and researcher- or research participant-produced visuals.

\section{eTourism and on how to address the smart city complexity}

\section{by Professor Marianna Sigala (University of South Australia), IJTC Theme Editor for eTourism}

There is no dispute that city tourism will continue to grow. Many tourism cities are also threatening to become from currently big to megacities faced with problems of the overloaded and insufficient carrying capacity of resources and infrastructure. Livability, sustainability, quality of life and (psychological, physical, socio-cultural and mental) well-being of tourists but also residents, security and safety, avoidance of commercialization/Disneyfication of cultural resources and spaces are only some of the top issues that many tourism cities already need to address. Nowadays, to achieve that, one does not have to work harder but smarter. Indeed, everything becomes smarter: smart citizens, smart tourists, smart destinations, smart tourism attractions, smart cars, smart houses, ... smart everything. In China alone, the government's priority is to have 40 smart cities by 2020 . It seems that the socio-technological factors that have contributed to the increase of tourism flows and inhabitants into cities can be used and are currently used to turn the issues around. One might call this strategy against overtourism and over-population 'fight them with their own weapons'.

Technological advances and their implications [social media, IoT, sharing economy/peer-to-peer platforms, e.g. Uber, Airbnb, the EasyJet /low-cost phenomenon in all sectors such as air carriers, accommodation), the increased people's mobilities (i.e. digital nomads) are indeed responsible for the 'Instagram' popularity and the overflow of tourists in numerous cities like Barcelona, Amsterdam], even in remote places like Hobart (Tasmania) whereby locals are displaced and/or complain about lack of housing, over-priced accommodation, conversion of residential areas into tourism hotspots. Simultaneously, many cities all over the globe have also been receiving more and more domestic and overseas immigrants and refugees, as a result, overseas political instability or the sought of domestic rural people seeking a better modern city life.

But at the same time, technological advances are being used and developed to make (tourism) cities more livable and sustainable: smart energy solutions manage waste and resources like water and electricity; big data (from Uber, social media etc.) inform urban planners on how to optimize public transportation systems and destination marketers to divert tourists off route and to less 'Instagrammed' popular hot spots; smart governance empowers citizens and tourists to raise their voice and participate in decision-making about their city lives and experiences; peer-to-peer platforms democratize access to the 'capitalist' economy and enable homelessly, disadvantaged groups, refugees to become micro-entrepreneurs (e.g. micro-restaurants, micro-tourist guides) in order to raise income, promote their 'own culture', avoid being ghettoized and so, become integrated within, be appreciated and understood by the local city communities; drones, artificial intelligence, robotics and teleporting will reduce transportation needs and problems (such as pollution and security) through urban delivery, monitoring, data collection. But then, all these new technologies raise new issues and dilemmas such as: digital 'discrimination' (why black Uber 
drivers and Airbnb hosts are less selected and lower paid?); privacy, ownership and security of big data; ethical and legal issues of drones and driverless cars 'programmed' to kill pedestrians over the passengers (who can decide about the value of the life of each individual, what the law says about the responsibility of programmers and machine learning devices, and what are the ethical issues of placing a value next to various people's lives?).

Overall, it seems that in this smart tourism cities world things become more complex and perplex to understand and manage. We are required to update and redefine legislation, cultural value systems, ethical values and lifestyles (what do we mean by micro-entrepreneur or digital nomad) now, but without currently knowing what the applications and implications of all these new sociotechnological changes and innovations are and could be.

\section{Social media and the City: Mediated gazes and digital traces}

\section{by Professor Ulrike Gretzel (University of Southern California), IJTC Theme Editor for Social} Media in City Tourism Marketing

Månsson (2011) argues that tourism spaces are becoming increasingly mediatized, with ordinary travellers and residents contributing to this phenomenon by sharing their experiences through an ever-growing array of social media applications. Jansson (2007) draws attention to the "close relationship between spatial and communicative practice" (p. 10) in the context of tourism and suggests that new media produce a different kind of space and a different kind of tourism by affecting the way tourists script, navigate and represent their tourism experiences. This is particularly the case for cities because the communicative density and heightened levels of connectivity in urban spaces facilitate social media use in critical ways (Magasic and Gretzel, 2017).

Social media play several important roles in tourism (Gretzel, 2018), and specifically in urban tourism. Social media use fuels our desire to travel because it creates vacation envy through exposure to others' enticing social media posts. Social media technologies are also incredibly 'needy' and persuade us to constantly post to please our social media audiences (Kozinets et al, 2016). They demand that we post extraordinary, share-worthy contents and tourist gazes are increasingly fixated on finding such experiences at tourist destinations (Dinhopl and Gretzel, 2016). Cities with their many walls, buildings, signs, art displays, public spaces, hidden alleyways, stairs, bridges, lights, shops, cafés, libraries, etc. offer an unlimited supply of objects and landscapes that can be framed in interesting ways for social media sharing.

Social media further inspire us to experience cities beyond the core tourism attractions by exposing us to curated lists of places that are instagrammable or 'trendy with the locals'. Based on the expanding universe of reviews, we can immediately judge whether these locales meet our preferences and unique needs. And we do no longer have to experience these places alone as social media afford new levels of social connectivity (Munar et al, 2013). Our urban adventures can be instantaneously shared via snaps or live videos with friends and family staying at the hotel or at home, with broader social media audiences or with tourism providers. At the same time, social 
media allow us to connect with other tourists or with locals by showing us who is near and interested/interesting. Cities, more so than any other destination type, deliver the necessary social density and diversity to foster such connections. Moreover, social media allow us to connect with our future cosmopolitan selves who can relive our city trips when social media 'memories' pop up on our screens.

Importantly, social media also provide us with new means to study these urban tourism experiences. They supply large quantities of geo-located digital traces of city tourists that can be quantitatively analysed to understand how urban spaces are navigated (Stienmetz, 2018). At the same time, they provide extremely rich experiential accounts of city tourism in a textual or visual form that can be scrutinized using netnographic techniques (Woodside et al, 2007). Seeing city tourism at this nexus of geographic and communicative practice, as suggested by Jansson (2007), therefore opens up many avenues to understanding tourism in urban environments that have yet to be explored by tourism researchers.

\section{The diversity of approaches to sustainability in tourism cities: initiating new research on dynamic and adaptive responses}

\section{by Dr Jonathon Day (Purdue University), IJTC Theme Editor for Sustainable Tourism}

While much of the conversation about sustainable tourism to date seems to focus on small-scale rural locations, the big story in the years to come is sustainable tourism in cities. In 2000, at the dawn of the new century, the Mohonk Agreement recognized that sustainable tourism was a set of principles that can be applied to all tourism operations - rural and urban. In the intervening years, the growth of cities and the continuing trends for urbanization have ensured that greater attention must be placed on the sustainability of urban tourism. Fortunately, the trend has begun, and greater attention is being paid to sustainability in urban destinations (Lu and Nepal, 2009). Nevertheless, as we move into 2020, the opportunity - and need for - research on sustainability in tourism cities is great.

The challenges of understanding sustainable tourism in cities are significant. Tourism is a complex, adaptive system (Farrell and Twining-Ward, 2005; Morrison et al, 2018), and this is never more evident than in urban tourism. In each city, a wide range of companies contribute to the provision of tourism services. In addition, tourism is dependent on services provided by organizations that do not even consider themselves part of the tourism system. Utilities providing energy, water, waste disposal, and transportation services all serving the community and tourists and each organization impacting the sustainability of the tourism in cities. Even at the individual level, the behaviour of each traveller visiting the city has the potential to either contribute positively or negatively to the city during their visit. Research on sustainable tourism in cities must be conducted examining the city as a system, as well as the contributions of organizations within the system and individual behaviour.

Tourism researchers must also recognize the tourism system is dynamic and adaptive (Day, 2016). Tourism organizations are both initiating changes and responding to them. In 2008, few could 
predict the impacts of Airbnb on tourism in cities. Today, cities continue to grapple with changes in disruptive technology. New forms of transportation are changing the streets and sidewalks of tourism cities. From the need to provide charging for electric vehicles, to new policies responding to the rapid rise of shared bikes and electric scooters, urban centres that host tourism must respond to the changing landscape. The opportunity to generate a greater understanding of these processes through longitudinal studies is great.

The scope of enquiry is great. Not only must we gain a greater understanding of what must be done, but how it will be done. The diversity of approaches to sustainability is exciting and offers a great opportunity for research. Cities are proving to be the laboratories for new policies and practices, often leading the way in new practices that tourism organizations must adopt. Smart tourism is improving the information available on which to build sustainability plans. Sill there is work to be done in understanding what works most effectively. And while much sustainability research has addressed what must be done to achieve greater sustainability in cities, less has been done on how we achieve these goals. Sustainability requires collaboration and cooperation between a variety of actors within the destination system, and it requires tourists and suppliers working together to achieve these goals.

Tourism researchers are making progress on many of these issues. As we address the challenges in our complex, ever-changing cities, we must be ready to embrace new perspectives and approaches. The challenge of sustainability in tourism cities encourages a multidisciplinary approach. Disciplines as varied as environmental engineering and sociology, consumer behaviour and town planning, hydrology and marketing, to name just a few, must all contribute to our growing understanding of the issues associated with urban sustainability and tourism.

The stakes have never been higher. While tourism has the potential to contribute to the achievement of sustainability goals, it may also contribute to many of the challenges facing the world. Environmental issues, economic development and social justice issues are evident across the tourism system - in cities that play host to many of the world's tourists. Indeed, beyond the general issues of sustainability in tourism, tourism cities are addressing new challenges including visitor management and overtourism.

\section{For residents or for tourists? The quality of life nexus in tourism cities}

by Dr Tina Šegota (University of Greenwich), IJTC Theme Editor of Quality for Life in Tourism Cities

In the light of recent residents' protests in Barcelona, Mallorca and Venice, to name a few, it is fair to conclude that the quality of life in tourism cities has been heavily challenged by increasing numbers of visitors and accompanying perceived negative impacts of tourism. Hence, the new buzzwords 'overtourism', 'overcrowding', 'anti-tourism' and 'tourism-phobia' were introduced across academic journals and other newspapers, igniting a new debate that may have rather existed for almost half of century. This is because the reasons for residents' mobilization against tourism and governments' actions to mitigate its negative impacts are not fully understood by the literature. 
Regardless of the resident attitudes towards tourism being one of the most extensively researched fields, dating back over more than 50 years, it failed to predict a tipping point for such extreme events. Note that many criticize the research filed as being unilateral and quantitative (in its own right), and that as such it failed to appreciate that perceived impacts or reactions to tourism are not singular or absolute (Deery et al, 2012; Nunkoo et al, 2013; Sharpley 2014; García et al, 2015; McKercher et al, 2015; Šegota et al, 2017).

Quality of life in tourism cities has been further challenged by the mediated gaze supported by social media and tourists' constant search for new, exciting and authentic experiences. In the constant battle for the economic development and growth originating from tourist visitations, some cities even went great lengths to attract visitors by immersing their identity to the identity liked by (potential) visitors. One such example is the city of Dubrovnik, a UNESCO Heritage Site since 1979, which has become a fantasyland for the Game of Thrones fans (Šegota, 2018a). The change of the city's identity has been greatly encouraged by the work of Croatian DMO in promoting the city as King's Landing on social media, which Šegota (2018b) describes as unintentional practices gone 'great'. However, the real issue is whether Dubrovnik or any other filming destination can continue to sustain itself as a significant heritage destination. Since 'new Dubrovnik' has been increasingly profiled and promoted as King's Landing, the city is now at risk of acquiring the image of a destination for film enthusiasts that only lasts a decade. That will, undeniably, result in fewer visitations over years to come as the outcome of decreased popularity of the film. However, it is not known and well-worth exploring, to what extent will the economic benefits from popular tourism decrease, leaving local residents with, on one hand, constant struggle for improving the sense of material well-being, and, on the other hand, challenges of city's identity with the effect to the sense of community well-being.

Importantly, the quality of life in tourism cities does not only apply to local residents but also to tourists that spend a considerable amount of time in cities. Thus, the quality of life has to be examined not only from the aspect of residents' well-being but also from tourists' well-being (Uysal et al, 2012). It was noted that a fully functioning tourism system should be a prerequisite for understanding and identifying both tangible and intangible benefits and costs of tourism (Uysal et al, 2012). Seeing urban tourism as an enabler of attaining a set of desired quality of life goals for residents and tourists whilst maintaining sustainable tourism system at a competitive edge, will open many new opportunities for research on allocating limited resources and developing appropriate tourism development and destination marketing strategies.

\section{Informing tourism policy and development with responsible tourism and ethnoscapes}

\section{by Dr Jithendran Kokkranikal (University of Greenwich), IJTC Theme Editor for Tourism Planning and Development}

Cities are no longer seen as mere ports of entry or transit points but have emerged as substantial tourist destinations that offer a wide range of tourist attractions and activities (Postma et al, 2018). Tourists visit cities for a variety of reasons, ranging from leisure to business and are a source of significant economic benefits. While being a source of dynamism and vitality, tourism has fast 
been becoming another source of pressure on the economy, infrastructure, society and environment to many cities. A number of cities have seen anti-tourism movements protesting against the disruption tourism has created to their lives (Seraphin et al, 2018). The complexities and challenges of city tourism, as a source of economic benefits and negative externalities, make it a major agenda for policy makers and planners. The implications to tourism policy and planning in cities are tremendous, so are the opportunities for tourism research in these areas.

Sustainability implications of city tourism have been and will continue to be a major research area, within which there is a need for further investigations on themes such as the circular economy and responsible tourism, both of which have significant policy and planning implications. Overtourism has emerged as a major issue in a number of city destinations, and a number of cities have seen anti-tourism protest movements (Seraphin et al, 2018). Population pressure on cities, which could be exacerbated by increasing tourist numbers necessitates further research on carrying capacity of urban destinations within the context of constantly evolving mobility patterns facilitated by technological advancements.

Most of the major city destinations have ethnoscapes (Razak, 2007) making them a kaleidoscope of eclectic cultural spaces, including the diaspora. Ethnoscapes and diaspora tourism thus form part of the policy research agenda for city tourism. Advancements in information and communication technologies have contributed to the emergence of the shared economy, a manifestation which in the accommodation sector (i.e., Airbnb) is said to have exacerbated urban inequality and turning many residential districts in the cities into tourist quarters.

\section{Lessons learnt and future challenges from tourism planning in Post-Communist countries}

\section{by Assoc. Professor Melanie K. Smith (Budapest Metropolitan University, The Hungarian Academy of Sciences and University of Tartu), IJTC Theme Editor for Cultural Tourism and Tourism in Post-Communist Countries}

The trajectories of post-socialist cities have not been uniform, nor should they be treated monolithically (Tsenkova, 2012; Berki, 2014; Banaszkiewicz et al, 2017). On the other hand, many post-socialist cities share a common history including the challenges of transition. Sýkora (2009) defined the post-socialist city as a temporarily existing, transitional city which adapted to new political and economic conditions in the transformation from communism to capitalism. This includes the development of tourism, which was limited to a great extent before 1989. Several major themes could be said to have emerged within the urban tourism research arena since 1989, including interpretation of the socialist past and dissonant heritage; national and city identity building and branding; cultural and creative industry developments; the role of tourism in urban rehabilitation and gentrification; the night-time economy; and (more recently) 'overtourism'.

During the early years after the fall of Communism, the question of national identity construction, image and brand building became important (Andrusz, 2004), an area within which tourism could play a major role. While international tourists were fascinated by the socialist heritage, postsocialist countries and especially their capital cities were keener to present a new identity to the world (Smith and Puczkó, 2010a). Socialist heritage often became dissonant, so street and square 
names were changed and the statues of communist leaders were removed or placed in remote statue parks or museums. Instead, of focusing on socialism, new narratives of place identity often invoked an idealised pre-socialist 'Golden Age' which was often the late nineteenth century (Young and Light, 2006). Many post-socialist cities are inherently cultural and historic and therefore have always promoted their heritage, museums and galleries (Hughes and Allen, 2005; Smith and Puczkó, 2012). Richards (2001) noted that there was a fall in the local consumption of 'high' culture in many post-socialist countries after 1989, mainly due to a lack of state subsidy and declining incomes. Thus, foreign tourism could provide the boost that was needed for many flagging cultural attractions.

Nevertheless, many countries suffered from a total lack of image (Olins, 2004; Smith and Puczkó, $2010 \mathrm{~b}$ ) and it was often a question of putting themselves on the European and international tourism map. Hall (2004) noted that many visitors harboured images of regional instability, poor service, infrastructure and the low quality of public facilities. However, tourism grew rapidly in the 2000s (Cudny, 2012), in a "desire to make up for lost time" (Banaszkiewicz et al, 2017:113). This was further accelerated by EU accession for many post-socialist countries in 2004, after which the advent of budget airlines changed the landscape of tourism quite considerably. By this time, firsttime 'curiosity' visitor numbers were decreasing (Rátz, 2004), but those interested in enjoying the night-time economy (NTE) and availing themselves of cheap alcohol was increasing. Relatively undesirable forms of tourism emerged in cities like Prague, Krakow and Tallinn, such as 'stag and hen' party drinking weekends (Iwanicki et al, 2016). Research has started to show that regardless of past developments, post-socialist cities are suffering similar effects of NTE and overtourism to western cities, accompanied by laissez-faire attitudes to urban and tourism planning, inconsistent and inadequate legal and regulatory frameworks, and inherent corruption (Tsenkova, 2012; Pixová and Sládek, 2017; Smith et al, 2017).

Future research might attempt to examine the inextricable connection between politics and tourism, especially with regard to changing identity and image construction, and the factors that determined the rapidly changing tourism landscapes from pre- and post-socialist heritage and cultural tourism to NTE-related 'overtourism'.

\section{Looking beyond the negative: Crises in tourism cities as a tool for learning and positive change}

by Assoc. Professor Joan C. Henderson (Nanyang Technological University), IJTC Theme Editor for Tourism Crisis Management for Cities

Crises take many forms and are an inescapable aspect of life. In terms of spatial scope, they range from the local to global and can strike at a city level with ramifications for its tourism. National and international crises are often shared by cities where adverse effects may be intensified. Developments in economic, political, socio-cultural and environmental domains separately and sometimes in combination can precipitate crises within an urban context in ways demonstrated by recent occurrences around the world. Major cities and especially capitals are places where financial and political power is concentrated, making them sites for expressions of internal dissent which 
can disrupt tourism. Terrorists too are attracted to cities as targets for their attacks because of population densities, capacity for damage and media interest. While tourism crises can be triggered by external factors beyond the control of the industry, they can be induced or exacerbated by industry weaknesses. The popularity of many cities can itself be a source of the crisis, illustrated by mounting resident opposition to what has been labelled 'overtourism'.

City destinations affected by crises face negative publicity, a problem which is aggravated in the era of modern information communication technologies, raising questions about the safety of visitors alongside any tourism industry investment. There are risks that reputations and images will be tarnished, although this depends on the city and nature and duration of the crisis together with the manner in which it is handled by civic authorities and businesses. Tourism has proved its resilience in the past and crisis-stricken destinations have been seen to recover quickly. Recovery and restoration of the status quo, or at least a state of near normality, is aided in the case of larger cities by their size and multi-functionality as centres of business and other types of travel in which there is less discretion than that for leisure purposes.

Nevertheless, anticipating and preparing for tourism crises are key responsibilities of metropolitan governments and the commercial sector. Looking ahead, cities confront numerous challenges with the potential to evolve into a situation of crisis which impacts on both domestic and international tourist arrivals. Prospective crises span a spectrum from a single incident to a chronic condition and encompass various sorts such as outbreaks of infectious disease, natural disasters, political and social unrest and financial shocks. Geographical location and stage of economic development play a part in vulnerability to crises and capacity to respond effectively with possible contrasts within and amongst regions worldwide. Crises also represent opportunities for learning and positive change which should not be overlooked.

It is therefore instructive to examine city experiences of crises globally with a view to better understand causes and catalysts, evolutionary processes, underlying dynamics and outcomes. Analyses can additionally yield useful insights into good practice regarding tourism crisis planning and management on the part of public and private agencies. There is an appreciation of the significance of urban tourism research generally and the need for further studies (Edwards et al, 2008; Ashworth and Page, 2011; Pearce and Pearce, 2017). Encouraging work related to issues of crises and dissemination of results is, therefore, an important task for the journal which is of relevance to both academics and practitioners.

\section{On terrorism and its challenges to freedom, mobility and way of life}

\section{by Asst. Professor Claudia Seabra (University of Coimbra), IJTC Theme Editor for Terrorism in Tourism Cities}

Terrorism is becoming frighteningly frequent. Recently, several countries have been targeted by terrorist attacks that are shaking important foundations upon which our identity is based: freedom, mobility, culture fruition and a happy way of life. The recent terrorist events mainly targeting important tourist sites and cities, beaches, museums, resorts, airports, train and subway stations, restaurants, discos, festivals, prove the high value of tourists as terrorist targets. Too many attacks 
targeted people who just wanted to be happy and have fun, working, living and travelling freely around the world...

These events marked the beginning of a new unsafety environment. The positions are radicalized; the discourses are hard and proactive. Many countries are preparing measures to strengthen security modifying its legislation to prevent further attacks especially in limiting the entries and visas. Some voices arise, asking for changes to the free movement of people especially in border controls limiting travelling. How do these attacks on freedom, mobility and way of life, condemned by all, manage to create, in turn, limitations to those same freedoms and way of life? There is a constant state of alertness that forces us to be in a constant state of discomfort that is almost comfortable. In turn, terrorism is having a strong impact on travel patterns. Tourists are avoiding destinations that experienced terrorist attacks changing the geography of travel. This reality is bringing to destinations and tourism firms new challenges to manage the damages caused by this unsafety environment. This daily contact with terrorism makes it strangely close and almost tolerable. It is urgent to understand this phenomenon. Hence, safety is one of the most fundamental conditions granted to human beings, it is an anthropological need and a vital part of the human condition. New research agendas should help to understand the real effects of terrorism on the individuals' life, to address both the material and the psychological cost of terrorism in the people's behaviour, namely in what regards to peoples' movement and travel.

\section{Resetting and re-exploring the foundations of tourists' behaviour in tourism cities}

\section{by Professor Philip Pearce (James Cook University), IJTC Theme Editor for Tourist Behaviour in Cities}

There are many themes about tourist behaviour which can be extended and revisited in future research about tourism cities. Four topics can be highlighted - wayfinding, dealing with others, appraising satisfaction, and storytelling. They all stand out as areas of particular interest. The need to refresh older studies exists because technology has reshaped some of what tourists have to do to cope with city visits. Further, new numbers and waves of tourist popularity in many cities present challenges which are unlike those seen in twentieth-century foundation studies. These changes demand that researchers build and regenerate what we know for the coming decade.

Wayfinding studies were built on tourists use of hand-held maps and followed the pioneering work of Lynch (1960). These early studies provided a coding system and interesting ideas about how to design maps for tourists. They partly answered questions about why men and women approach the task of mapping the city differently and avoid getting lost (not always successfully). With mobile phones, satellite technology and the use of advisory directional aids, the support systems for finding the way in a city are markedly different. Nevertheless, how individuals negotiate, use and argue over the right turns to take or the most desirable option to visit still matter and are worth studying - both for the harmony of the travel party and for the businesses seeking to attract their customers.

Dealing with others in city tourism has become the hot topic of this decade. Tourists have to deal with the problem of overtourism, at least for the duration of their visit. Local citizens, of course, have to deal with the problem over several months, and sometimes for almost twelve months of the year. Our models of tourist-tourist and tourist-local contact were built in less busy times (cf. Amir, 
1969; Hottola, 2005). The extent to which tourists annoy one another and frustrate the local community may have to be reconceptualised with new social representations of the problem of crowding and stresses on human and physical resources. Significant shifts in how city tourist experiences are redesigned to account for the large volumes of people represents a conceptually interesting challenge with important applied consequences.

Satisfaction, like the other foundation concepts considered here, was initially emphasised in consumer studies in the 1950s. By the time the Rolling Stones sang about the topic in the 1960s, it was an entrenched dependent variable in business and marketing. As shifts in the economy developed towards the end of the decade, the foundation idea that satisfaction was all that mattered in evaluating tourist behaviour was wearing thin; other outcomes such as learning, selfdevelopment, personal growth, and having a low impact started to appeal as alternative measures of the worth of the holiday. In looking forward, the need to embrace a wider range of outcomes to assess the meaning of city trips is now on the agenda of contemporary researchers and links to motivation theories, such as my own travel career pattern (Pearce, 2005; 2011), may suggest more factors to consider when reviewing the benefits of a city holiday.

Telling one's travel story has also changed over the last 50 years. When tourism studies started to blossom, there were not so many travellers and certainly relaying messages about international and domestic holidays was a snail mail process. On return to one's home community, the full events of the holiday and its sights and sounds were relayed to audiences for the first time. Now in the social media world, and with the greater numbers of experienced travellers, it is much harder for the returning tourist to have something novel to say. Many struggle to avoid repeating the themes already broadcast through Facebook, WeChat or Twitter. In essence, tourists have to work harder to exploit social status and personal gain once easily acquired by travelling to a city. There is research to be done, therefore, on what are the best city tourism stories, and importantly, how can an understanding of these stories, translate into marketing and business opportunities for destination marketers.

City tourism has deep roots in many cultures and societies. Pathways to study aspects of tourists' behaviour were set when tourism flourished in the second half of the twentieth century. It is desirable now to reset and re-explore some of these foundation directions for the next decade.

\section{Research into business tourism: past, present and future}

by Dr Rob Davidson (MICE Knowledge and University of Greenwich), IJTC Theme Editor for Meetings, Incentives, Conferences and Exhibitions (MICE)

A significant proportion of the visitors to cities around the world are business tourists - people attending meetings, conferences, trade shows and other types of events connected with their employment or economic activity. This form of tourism brings a range of benefits to cities, principally economic, as the daily expenditure of business tourists is generally much higher than that of leisure visitors. For example, in 2017 the daily expenditure of international business visitors to Australian cities was almost double that of holiday visitors to those destinations in the same 
year. In addition, for most cities, business tourism is far less seasonally-concentrated than leisure tourism, decreasing in volume only at holiday periods and weekends.

In recognition of business tourism's potential to create additional profits for local hospitality businesses and employment for their citizens, a growing number of cities around the world have developed their infrastructure for this segment of the tourist market, constructing conference centres and exhibition halls in which business events may be held. The private sector has responded in a similar manner, with the opening of new convention hotels in destinations worldwide. This physical infrastructure has been widely complemented by the building of a human infrastructure for business tourism, comprising Convention Bureaux and other destination marketing organisations with the explicit role of attracting large-scale business events to their cities.

Although research into business tourism often appears to pale into significance by comparison with the volume of research into leisure tourism, there has been a recent increase in both the quantity and quality of academic research focusing on this topic. But this growth has been slow in coming. In one of the first reviews of academic research into business events, Yoo and Weber (2005) declared that, despite strong growth in flows of global business tourism over the previous quarter century, it remained under-represented in tourism scholarship as a whole. Five years later, Stetic and Simicevic (2010) still considered that business tourism had not attracted the attention of a number of researchers that was commensurate with its economic importance. But Mair's (2012) review of the academic business tourism literature from 2000-2009 suggested that interest in this form of tourism was increasing, with researchers focusing largely upon the economic impact of business tourism and the site selection process of conference organisers. Her review identified further areas which have been the focus of considerable research efforts in the period 2000-2009. These include the evaluation of satisfaction by meeting planners, the role of destination image in conference attendance and the decision-making process of conference attendees. But perhaps the most valuable contribution of Mair's review was her highlighting of important research gaps. She identified these as the social and environmental impacts of business events; climate change and events; incentive travel; and qualitative research (into, for example, the meanings that individuals attach to business events, or about their experience of attending a business event).

It is perhaps the last of these that offer the greatest potential for providing useful insights into the crucial demand-side factors in the business tourism market, as opposed to the more quantitative supply-side research that has dominated this field of enquiry until recently. We need to achieve a much better understanding of business tourists' experience of visiting our cities and their journeys through those experiences, from the initial invitation to attend a business event to departing from the destination when that event ends. For example, we need a greater understanding of topics such as: What role does destination image play in the potential business tourist's decision of whether or not to accept the invitation? How does the experience of business tourists differ from that of leisure visitors to cities? What are the factors that come into play in the business tourist's decision on whether or not to extend their business trip for leisure purposes by spending a few extra days in the city? These, I believe, will be among the themes that will increasingly attract the interest of researchers over the next few years. 


\section{The need for different approaches to understanding special interest tourism in the urban context}

\section{by Professor Cina Van Zyl (University of South Africa), IJTC Theme Editor for Special Interest} Tourism

Tourism, along with other key pillars, constitutes a central component in the economy, social life and the geography of many cities in the world and is thus a key element in urban development policies. Urban tourism can represent a driving force in the development of many cities and countries; tourism is intrinsically linked to how a city develops itself and provides more and better living conditions to its residents and visitors (UNWTO, 2018a). This is more particularly valid for Special Interest Tourism (hereinafter SIT).

The developments during the current decade point out a shift of tourism in focus towards innovation and experiences, and tourists' demand for diverse and immediate experiences in cities (UNWTO, 2018b). The various forms of SIT - heritage, cultural, events, culinary/gastronomic, etc. - constitute, in our humble opinion, the mainstream of these experiences. This context involves an imperative to improve our understanding and knowledge of the various factors influencing tourism in cities and the related challenges.

A better understanding is needed, and this is the role of academic research. Researchers should aim at exploring and gaining insights on the various issues of the topic of SIT in the urban context and settings. Academic research - conceptual approaches and empirical studies - should investigate the issues and aspects related to SIT from the perspective of different disciplines, i.e. psychology, anthropology, sociology, economy, marketing and management. Some suggestions for future research, classified into four perspectives or streams, are formulated below.

On management in tourism cities: understand and manage visitor growth and emerging challenges; visitor management challenges in urban contexts; adequate strategies and actions plans to manage tourism in urban destinations to the benefit of visitors and residents alike; ensure sustainable policies and practices that minimize adverse effects of tourism on the use of natural resources, infrastructure, mobility and congestion, as well as its socio-cultural impact; appropriate governance models to address the challenges facing urban tourism; collaboration and cooperation approaches in fulfilling tourism's potential (based on stakeholder theory); approaches and strategies to build shared responsibility amongst stakeholders directly or indirectly involved in urban tourism for sustainable development.

On-demand/tourist consumers: the antecedents/motivations for and the influencing factors of consumers of SIT; the encounter between hosts and guests and their interaction in cities; the exchange value consumption in psychological, and anthropological terms; creating innovative experiences, experiences design and development; the factors influencing the consumers' perceived value and satisfaction of experiential services (assessment); comparative approach and investigation to conventional forms of tourism; and Millennials vs Generation Z (similarities and differences). 
On supply and business perspective: interesting avenues for future research include issues such as the impact and contribution of SIT to entrepreneurship; from marketing management perspective the business models of SIT (critical success factors as well as their marketing strategies); the strategies adopted and implemented by businesses in providing high quality experiences as well as quality of tourists' experiences determined by sustainability, accessibility, connectivity, and infrastructure.

On hosting community/urban area: academic research should explore the perceptions of local populations and their level of satisfaction, analysis of residents' perceptions towards SIT in cities; the effects of SIT on cities and local populations such as the perceptions of residents and the conflicts among different stakeholders; the economic effects/impact on hosting cities (local economy); as well as the contribution of SIT in job creation and employment by local tourism businesses; (and strategies and approaches in involving all stakeholders, bringing residents and visitors together and adopting careful planning which respects the limits of capacity and the specificities of each urban destination.

\section{Conservation of 'nature in the city' and its importance for city tourism}

by Assoc. Professor David Newsome (Murdoch University), IJTC Theme Editor for Ecotourism and Liveable Cities, and James Hardcastle (International Union for Conservation of NatureIUCN, Switzerland)

Natural vegetation, greenspace comprising parks, water features and native trees, and associated wildlife (particularly birds) are increasingly important as recreational resources for urban people who are in the pursuit of healthy lifestyles and hobbies, and for those who are promoting green aspects of city tourism. 'Nature in the city' and the emerging importance of natural areas in 'city liveability' was raised in the first issue of the International Journal of Tourism Cities (Jones and Newsome, 2015). In recent years, the importance of nature in cities has been highlighted according to the health benefits for resident populations (Bratman et al, 2012; Shanahan et al, 2015), social and psychological benefits (Gladwell et al, 2013) and in regard to the conservation of urban nature (Müller and Werner, 2010). However, as posited by Jones and Newsome (2015), emphasising the importance of natural areas in urban environments, in regard to city liveability and tourism potential, still requires further attention and recognition. We believe that the next phase in exploring the context of nature in the city is in regard to acknowledging and extending the views forwarded by recent research (Dallimer et al, 2012; Keninger et al, 2013; Taylor and Hochuli, 2015) and setting this in the context of internationally recognised standards and criteria for the conservation of important natural and cultural values, such as the IUCN Green List (IUCN, 2018; Wells et al, 2016).

Although many cities feature environmental highlights a few offer natural values as part of a 'top ten' list of tourist attractions. A brief Trip Advisor search for some representatives of the world's most populous cities, 'city proper' shows that very few of them feature even one 'natural' area or attraction within the top 10 things to do within or nearby city limits yet, at the same time, they collectively include more than 175 million people. For example, cities such as London, Tokyo, 
Beijing and Istanbul receive millions of visitors per year. Providing nature-based tourism and recreational experiences within cities have incredible health, education and well-being benefits for people and communities and urban societies alike.

In addition, providing local natural attractions can help reduce the 'export' of tourists seeking experiences in other places, provide benefits for locals and add value for travellers who are interested in reducing their global carbon footprint from tourism (McKercher et al, 2010; Juvan and Dolnicar, 2014).

In addition, urban protected areas are generally viewed as a low priority for biodiversity conservation (Watson et al, 2014), and subsequently, do not yet receive the attention and support of some international nature conservation groups. Yet such natural areas can help to foster city liveability and serve as tourist attractions in their own right (Jones and Newsome, 2015). However, the situation is changing. For example, the IUCN maintains an urban protected areas specialist group within the World Commission on Protected Areas (WCPA), IUCN resolutions call for more focus on 'healthy parks, healthy people' and emphasise the role of protected areas in providing ecosystem-based disaster risk reduction. Moreover, ecosystem services such as clean air and water are increasingly recognised to play a vital role in adaptation to climate change in and around cities. There is also a World Bank-led programme on resilient cities and campaigns to foster greener cities, such as the 'London National Park' campaign (London National Park City, n.d.).

Protected areas in cities such as areas with a defined nature conservation value, i.e. species, habitat, ecosystem services, biodiversity and educational/cultural values linked to nature, are increasingly being recognised as important for conservation. In some cases, 'natural areas' in cities are being restored and actively managed, or even created (Ikin et al, 2015; Simpson and Newsome, 2017).

Moreover, it is important to appreciate that the collective success of conserved areas in cities depends on an overall plan and integration at the landscape scale (Antognelli and Vizzari, 2017). IUCN's new Green List sustainability standard (IUCN, 2018) could help frame success for urban conservation areas and provide an incentive for dedicated investment into master-planning, and in achieving and maintaining good performance at sites within cities and across clusters of 'sites' sharing similar values.

Research opportunities include the development of standard indicators for the conservation of nature in cities, a specific focus for indicators on visitation, education, access and equity, and on good governance and management that helps expand and connect natural values across a cityscape and landscape. In this regard, IUCN Green List expert evaluators include urban experts. Managers of natural sites in cities could be encouraged to jointly apply for the IUCN Green List where they share natural values, or where conservation outcomes are dependent on collective performance and good management. Such international standards will foster urban tourism and additionally lead to city reserves and other green spaces becoming features of city tourism to be valued and marketed in their own right. Such activities are likely to further enhance the tourism value of existing nature spaces in cities such as Xi Xi Wetland, Hangzhou, China; Son Tra Peninsular in Da Nang, Viet Nam; Kings Park in Perth, Australia and Central Park in New York, USA. 


\section{In conclusion: Opening new research avenues with visual research methodologies \\ by Dr Tijana Rakić (University of Brighton), IJTC Theme Editor for Visual Research Methodologies}

Although visual methodologies are still on the methodological margins of tourism studies (Rakic and Chambers, 2012a), the past decade has witnessed the significant proliferation of a variety of visual approaches to research among tourism scholars. Visual methods are not only increasingly perceived as valid and legitimate methods, but also as methods which can enable the production of knowledge on previously relatively under-researched themes.

Visual methodologies offer numerous opportunities for research on tourism cities in that visual approaches to research can, for example, enable scholars to collect and analyse a variety of materials containing (audio)visual representations of a destination. Examples of such materials include tourist photographs or videos, promotional materials, brochures, postcards, news reports and articles, films, TV-Series, documentaries, animations, travel vlogs and blogs. The importance of sourcing and analysing these materials through analytical approaches such as discourse, narrative, content or semiotic analyses lies in the fact that these materials project, and inevitably also partly inform, the image of a destination.

In addition, numerous possibilities for research on tourism cities are also afforded by elicitation techniques and researcher- or research participant-produced visuals (Rakić and Chambers, 2012b). Importantly, fieldwork methods such as (audio)visually recorded sessions of participant observation and interviews can also enable researchers to produce visual research outputs such as a photographic exhibition, a video or an academic documentary (see Rakić and Chambers, 2010; Rakić, 2010), assisting researchers to inspire further discussions about their project, its findings and implications among the wider public, policymakers or stakeholders of tourism development at a destination.

Given the importance of the visual imagination of a destination prior to visitation, the importance of visually recording (and in some cases live streaming) the tourist experience while at a destination, and the role of the visuals such as photographs and videos in remembering and narrating the tourist experience, visual methodologies are likely to be at the heart of research on tourist cities in the future. 


\section{References}

Amir, Y. (1969), "Contact hypothesis in ethnic relations", Psychological Bulletin, Vol. 71, pp. 319-342.

Andrusz, G. (2004), "From Wall to Mall", keynote presented at the Winds of Societal Change: Remaking Postcommunist Cities International Conference, 18-19 June, University of Illinois, Urbana-Champaign.

Antognelli, S. and Vizzari, M. (2017), "Landscape liveability spatial assessment integrating ecosystem and urban services with their perceived importance by stakeholders", Ecological Indicators, Vol. 72, pp. 703-725.

Ashworth, G. and Page, S.J. (2011), "Urban tourism research: Recent progress and current paradoxes", Tourism Management, Vol. 32 No.1, pp. 1-15.

Banaszkiewicz, M., Graburn, N. and Owsianowska, S. (2017), "Tourism in (Post)socialist Eastern Europe", Journal of Tourism and Cultural Change, Vol. 15 No. 2, pp. 109-121.

Berki, M. (2014), "Return to the road of capitalism: Recapitulating the post-socialist urban transition”, Hungarian Geographical Bulletin, Vol. 63 No.3, 319-334.

Bratman, G.N., Hamilton, P. and Daily, G.C. (2012), "The impacts of nature experience on human cognitive function and mental health", New York Academy of Sciences, Vol 1249: 118136.

Dallimer, M., Irvine, K.N., Skinner, A., Davies, Z.G., Rouquette, J.R., Maltby, L.L., Warren, P.H., Armsworth, P.R. and Gaston, K.J. (2012), "Biodiversity and the feel-good factor: Understanding associations between self-reported human well-being and species richness", BioScience, Vol 62, pp. 47-55.

Day, J. (2016), An Introduction to Sustainable Tourism and Responsible Travel, Kindle edition, available at https://www.amazon.com/dp/B01HJ8KXIY/ref=rdr kindle ext tmb (accessed 5 October 2018).

Deery, M., Jago, L. and Fredline, L. (2012), "Rethinking social impacts of tourism research: A new research agenda", Tourism Management, Vol. 33 No. 1, pp. 64-73.

Dinhopl, A. and Gretzel, U. (2016), "Selfie-taking as touristic looking", Annals of Tourism Research, Vol. 57, pp. 126-139.

Edwards, D., Griffin, T. and Hayllar, B. (2008), "Urban tourism research: Developing an agenda", Annals of Tourism Research, Vol. 35 No. 4, pp. 1032-1052.

Farrell, B. and Twining-Ward, L. (2005), "Seven steps towards sustainability: Tourism in the context of new knowledge”, Journal of Sustainable Tourism, Vol. 13 No. 2, pp. 109-122.

Garcia, A.F., Balbuena Vazquez, A. and Cortis Maceas, R. (2015), "Resident's attitudes towards the impacts of tourism”, Tourism Management Perspectives, Vol. 13, pp. 33-40.

Gladwell, V.F., Brown, D.K., Wood, C., Sandercock, G.R. and Barton, J.L. (2013), "The great outdoors: How a green exercise environment can benefit all", Extreme Physiology \& Medicine, Vol. 2 No. 1, p. 3.

Gretzel, U. (2018), “Tourism and Social Media", in Cooper, C., Gartner, W., Scott, N. and Volo, S. (Eds.), The Sage Handbook of Tourism Management, Sage, Thousand Oaks, pp. 415-432. Hall, D. (2004), "Branding and national identity: the case of Central and Eastern Europe", in Morgan, N., Pritchard, A. and Pride R. (Eds.), Destination Branding: Creating the Unique Destination Proposition, Butterworth Heinemann, Oxford, pp. 111-127. 
Hottola, P. (2004), “Culture confusions: Intercultural adaptation in tourism”, Annals of Tourism Research, Vol. 31 No. 2, pp. 447-466.

Hughes, H. and Allen, D. (2005), "Cultural tourism in Central and Eastern Europe: the views of 'induced image formation agents", Tourism Management, Vol. 26 No. 2, pp. 173-183.

Ikin, K., Le Roux, D.S., Rayner, L., Villasenor, N.R., Eyles, K., Gibbons, P., Manning, A.D. and Lindenmayer, D.B. (2015), "Key lessons for achieving biodiversity-sensitive cities and towns", Ecological Management and Restoration, Vol. 16, pp. 206-214.

IUCN (2016), IUCN Green List of Protected and Conserved Areas: User Manual, Version 1.0.

The global standard for protected areas in the 21st Century. International Union for

Conservation of Nature and Natural Resources, Gland, Switzerland.

IUCN (2018), IUCN Green List of Protected and Conserved Areas: Standard, Version 1.1., The global standard for protected areas in the 21 $1^{\text {st }}$ Century, International Union for Conservation of Nature and Natural Resources, Gland, Switzerland.

Iwanicki G., Dłużewska A. and Smith, M.K. (2016), “Assessing the level of popularity of European stag tourism destinations", Quaestiones Geographicae, Vol. 35 No. 3, pp. 15-29.

Jansson, A. (2007), "A sense of tourism: New media and the dialectic of encapsulation/decapsulation”, Tourist Studies, Vol. 7 No. 1, pp. 5-24.

Jones, C. and Newsome, D. (2015), "Perth (Australia) as one of the world's most liveable cities: A perspective on society, sustainability and environment", International Journal of Tourism Cities, Vol. 1, pp. 18-35.

Juvan, E. and Dolnicar, S. (2014), "Can tourists easily choose a low carbon footprint vacation?", Journal of Sustainable Tourism, Vol. 22, pp. 175-194.

Keniger, L.E., Gaston, K.J., Irvine, K.N. and Fuller, R.A. (2013), "What are the benefits of interacting with nature?", International Journal of Environmental Research and Public Health, Vol. 10, pp. 913-935.

Kozinets, R., Patterson, A. and Ashman, R. (2016), "Networks of desire: How technology increases our passion to consume", Journal of Consumer Research, Vol. 43 No. 5, pp. 659-682. London National Park City (n.d.), http://www.nationalparkcity.london/ (accessed 22 September 2018).

Lu, J. and Nepal, S. (2009), "Sustainable tourism research: An analysis of papers published in the Journal of Sustainable Tourism”, Journal of Sustainable Tourism, Vol. 17 No. 1, pp. 5-16. Lynch, K. (1960), The image of the city, MIT Press, Boston, MA.

Magasic, M. and Gretzel, U. (2017), "Three Modes of Internet Connectivity during Travel: Remote, Transit and Residential”, paper presented at the ENTER 2017 Conference on Information and Communication Technologies in Tourism, 24-26 January, Rome, Italy, available at http://ertr.tamu.edu/content/issues/enter-2017-volume-8-research-notes/ (accessed 5 October 2018).

Mair, J. (2012), “A review of business events literature”, Event Management, Vol. 16 No. 2, pp. 133-141.

Månsson, M. (2011), "Mediatized tourism”, Annals of Tourism Research, Vol. 38 No. 4, pp. $1634-1652$. 
McKercher, B., Prideaux, B., Cheung, C. and Law, R. (2010), “Achieving voluntary reductions in the carbon footprint of tourism and climate change", Journal of Sustainable Tourism, Vol. 18, pp. 297-317.

McKercher, B., Wang, D. and Park, E. (2015), "Social impacts as a function of place change", Annals of Tourism Research, Vol. 50, pp. 52-66.

Morrison, A., Lehto, X. and Day, J. (2018), The Tourism System (8th ed.). Kendall Hunt, Dubuque, Iowa.

Müller, N. and Werner, P. (2010), "Urban biodiversity and the case for implementing the convention on biological diversity in towns and cities", in Urban biodiversity and design, Muller, N., Werner, P. and Kelcey, J. (Eds.), Blackwell Publishing, London, pp. 1-33.

Munar, A.M., Gyimóthy, S. and Cai, L. (Eds.). (2013), Tourism Social Media: Transformations in Identity, Community and Culture. Emerald Group Publishing, Bingley, UK.

Nunkoo, R., Smith, S.L.J. and Ramkissoon, H. (2013), "Residents' attitudes to tourism: a longitudinal study of 140 articles from 1984 to 2010", Journal of Sustainable Tourism, Vol. 21 No. 1, pp. 5-25.

Olins, W. (2004), "Branding the nation: the historical context", in Morgan, N., Pritchard, A. and Pride R. (Eds.), Destination Branding: Creating the Unique Destination Proposition, Butterworth Heinemann, Oxford, pp. 17-25(23).

Pearce, J.R. and Pearce, P.L. (2017), "Retro-methodologies: Insights for city tourism research", International Journal of Tourism Cities, Vol. 3 No. 1, pp. 17-29.

Pearce, P.L. (2005), Tourist behaviour: Themes and conceptual schemes, Channel View, Clevedon.

Pearce, P.L. (2011), Tourist behaviour and the Contemporary World, Channel View, Bristol. Postma, A., Buda, D. and Gugerell, K. (2018), "The future of city tourism", Journal of Tourism Futures, Vol. 3 No. 2, pp. 95-101.

Rakić, T. (2010), "Tales from the field: video and its potential for creating cultural tourism knowledge", in Richards, G. and Munsters, W. (Eds.), New Perspectives on Cultural Tourism Research, CABI, Wallingford, pp. 129-140.

Rakić, T. and Chambers, D. (2010), "Innovative techniques in tourism research: an exploration of visual methods and academic filmmaking”, International Journal of Tourism Research, Vol. 12 No. 4, pp. 379-389.

Rakić, T. and Chambers, D. (Eds.) (2012a), An Introduction to Visual Research Methods in Tourism, Routledge, London.

Rakić, T. and Chambers, D. (2012b), "Introducing visual methods to tourism studies", in Rakić, T. and Chambers D. (Eds.), An Introduction to Visual Research Methods in Tourism, Routledge, London, pp. 3-14. Rátz, T. (2004), European Tourism, Kodolányi János University College, Székesfehérvár. Razak, V. (2007), "From culture areas to ethnoscapes: An application to tourism development", The Journal of Regional Analysis and Policy, Vol. 37 No. 3, pp. 199-212.

Richards, G. (2001), "The development of cultural tourism in Europe", in Richards, G. (Ed.), Cultural attractions and European tourism, CABI, Wallingford, pp. 3-29.

Seraphin, H., Sheeran, P. and Pilato, M. (2018), "Over-tourism and the fall of Venice as a destination", Journal of Destination Marketing and Management, Vol. 9, pp. 374-376. 
Shanahan, D.F., Lin, B.B., Bush, R., Gaston, K.J., Dean, J.H., Barber, E. and Fuller, R.A. (2015), "Toward improved public health outcomes from urban nature", American Journal of Public Health, Vol. 105, pp. 470-477.

Sharpley, R. (2014), "Host perceptions of tourism: A review of the research", Tourism Management, Vol. 42, pp. 37-49.

Simpson, G. and Newsome, D. (2017), "Environmental history of an urban wetland: From degraded colonial resource to nature conservation area", Geography and Environment, Vol. 4 No. 1, pp. 1-18.

Smith, M.K. and Puczkó, L. (2010a), "Post-socialist identity construction in Hungary: A multilevel branding approach", in Frew, E. and White, L. (Eds), Tourism and National Identity: An International Perspective, Routledge, London, pp. 38-51.

Smith, M.K. and Puczkó, L. (2010b), "Out with the Old, in with the New? 20 years of Post-Socialist Marketing in Budapest", Journal of Town and City Management, Vol. 1 No. 3, pp. 288-299.

Smith, M.K. and Puczkó, L. (2012), "Budapest: from socialist heritage to cultural capital?", Current Issues in Tourism, Vol. 15 No. 1-2, pp. 107-119.

Stetic, S. and Simicevic, D. (2010), "Business travellers-An important segment of tourism development in Serbia", in Mass tourism vs niche tourism: Cyprus 2010 ATLAS conference 3-5 November Limassol - extended abstracts, Arnhem, ATLAS, pp. 98-105.

Stienmetz, J.L. (2018), "Deconstructing visitor experiences: Structure and sentiment”, in Information and Communication Technologies in Tourism 2018, Springer, Cham, pp. 489-500. Sykora, L. (2005), “Gentrification in post-communist cities”, in Atkinson, R. and Bridge, G. (Eds), Gentrification in a global context: The new urban colonialism, Routledge, New York, NY, pp. 91106.

Šegota, T. (2018a), "Creating (extra)ordinary heritage through film-induced tourism: The case of Dubrovnik and Game of Thrones", in Palmer, C. and Tivers, J. (Eds.), Creating Heritage for Tourism, Routledge, London, pp. 115-126.

Šegota, T. (2018b), "(G)A(i)ming at the throne: social media and the use of visitor-generated content in destination marketing”, in Lundberg, C. and Ziakas, V. (Eds.), Handbook on Popular Culture and Tourism, Routledge, London, pp. 427-438.

Šegota, T., Mihalič, T. and Kuščer, K. (2017), "The impact of residents' informedness and involvement on their perceptions of tourism impacts: The case of Bled", Journal of Destination Marketing and Management, Vol. 6 No. 3, pp. 196-206.

Taylor, L. and Hochuli, D.F. (2015), "Creating better cities: how biodiversity and ecosystem functioning enhance urban residents' wellbeing”, Urban Ecosystems, Vol. 18, pp. 747-762.

Tsenkova, S. (2012), "Planning trajectories in post-socialist cities: Patterns of divergence and change", Urban Research and Practice, Vol. 7 No. 3, pp. 278-301.

UNWTO (2018a), 7th UNWTO Global Summit on Urban Tourism, 2018, Seoul, Republic of Kore, available at http://marketintelligence.unwto.org/7th-global-summit-urban-tourism (accessed 5 October 2018).

UNWTO (2018b), "New UNWTO report helps cities manage impact of tourism", press release PR No. 18066, Madrid, Spain, 18 September.

Uysal, M., Sirgy, J.M. and Perdue, R.R. (2012), "The missing links and future research directions", in Uysal, M., Perdue, R.R. and Sirgy, J.M. (Eds.), Handbook of Tourism and Quality- 
of-Life Research: Enhancing the Lives of Tourists and Residents of Host Communities, Springer, New York, NY, pp. 669-685.

Watson, J.E.M., Dudley, N., Segan, D.B. and Hockings, M. (2014), “The performance and potential of protected areas", Nature, Vol. 515, pp. 67-73.

Wells, S, Addison, P.F.E, Bueno, P.A., Costantini, M., Fontaine, A., Germain, L., Lefebvre, T., Morgan, L., Staub F., Wang, B., White, A. and Zorilla, M.X. (2016), "Using the IUCN Green List of Protected and Conserved Areas to promote conservation impact through marine protected areas", Aquatic Conservation, Vol. 26, pp. 24-44.

Woodside, A.G., Cruickshank, B.F. and Dehuang, N. (2007), "Stories visitors tell about Italian cities as destination icons", Tourism Management, Vol. 28 No. 1, pp. 162-174.

Yoo, J.J-E. and Weber, K. (2005), "Progress in convention tourism research", Journal of Hospitality \& Tourism Research, Vol 29, pp. 194-222.

Young, C. and Light, D. (2006), "Communist heritage tourism: between economic development and European integration", in Hassenpflug, D., Kolbmüller, B. and Schröder-Esch, S. (Eds), Heritage and media in Europe - contributing towards integration and regional development, Bauhaus Universität, Weimar, pp. 249-263. 